Eastern Illinois University

The Keep

Faculty Research \& Creative Activity

History

July 2003

\title{
Welfare and Warfare: American Organized Labor Approaches the Military-Industrial Complex, $1949-1964$
}

Edmund F. Wehrle

Eastern Illinois University, efwehrle@eiu.edu

Follow this and additional works at: http://thekeep.eiu.edu/history_fac

Part of the History Commons

\section{Recommended Citation}

Wehrle, Edmund F., "Welfare and Warfare: American Organized Labor Approaches the Military-Industrial Complex, 1949-1964" (2003). Faculty Research \& Creative Activity. 19.

http://thekeep.eiu.edu/history_fac/19 


\title{
Welfare and Warfare: American Organized Labor Approaches the Military- Industrial Complex, 1949--1964
}

\author{
Edmund F. Wehrle
}

Historians have been almost unanimous in condemning American organized labor's postwar relationship with the military-industrial complex.(1) Most follow Nelson Lichtenstein's assessment of a movement sacrificing militancy in favor of a junior partnership in a corporate state dominated by employers and the state. This capitulation legitimized managerial authority, validated a regressive economic system, and latched labor's wagon to a reactionary foreign policy and an emerging garrison state(2) This latter relationship, in particular, has galled critics of American organized labor. By the 1970s, they could assert, as did even "labor priest" Monsignor Charles Owen Rice, that labor had become a "lackey of militarism."(3)

In the postwar period, most trade unions supported the overall contours of U.S. official policy--from trade liberalization, to the Cold War, to the expansion of the militaryindustrial complex--but this article argues that decisions made by organized labor leaders must be understood within the context of increasingly limited options. After World War II, organized labor faced a host of hostile forces. In the absence of alternatives, the mainstream of organized labor embraced defense spending for the jobs it provided and for the influence that labor might wield in the semi-public defense-sector economy. Beginning in the late 1940s, organized labor developed and promoted its own separate vision of the "warfare state," in which defense dollars, in the absence of other public funding, would be harnessed to address pressing social and economic needs. Trade unionists promoting these initiatives clashed severely with military officials and civilian businessmen recruited to streamline, systematize, and rationalize the emerging militaryindustrial complex. Ultimately, they met with only temporary, limited success. But in labor's actions and agenda can be found evidence of a realistic approach to shaping and humanizing the complex postwar economy--an approach aimed at addressing the human impact of capitalism rather than slavishly following the logic of the market(4)

Students of labor history, it is hoped, will find in this study a realistic context in which to assess the actions of organized labor's approach to defense policy. For students of civilmilitary relations, it suggests something of the competing visions and forces shaping military policy and the emerging military-industrial complex.

\section{Postwar Opportunity and Disappointment}

The roots of labor's campaign to shape the national security state can be found in two interrelated developments: the eclipsing of labor's voluntaristic approach to the state in favor of a more cooperative model, and the embrace by labor of an economic outlook that can best be described as Social Keynesianism.(5) Inspired by the New Deal, many progressive unionists, especially those associated with the Congress of Industrial 
Organizations (CIO), were attracted to the potential of greater labor/state cooperation and planning. However, the confusion and politics of World War II planning, in which labor often saw its voice drowned out by business interests, cooled enthusiasm for such corporate endeavors. Increasingly, both the CIO and the American Federation of Labor (AFL), with its more conservative orientation toward skilled workers, turned instead to the promise of a pluralistic state and Keynesian economics, in which government played a defined and confined role.

To some historians, in this period, organized labor made an unfortunate retreat from larger goals of social justice and planned economics in favor of material gains through collective bargaining and a closer relationship with the Democratic Party.(6) Such a view, however, ignores the hostile political and economic climate facing organized labor in the immediate postwar years. A wave of bitter strikes in 1946 fed a public backlash, culminating in a conservative takeover of Congress that year. Truman's Fair Deal welfare initiatives quickly collapsed, and business launched an aggressive campaign to regain prerogatives under assault since the inception of the New Deal. (7) The flood of bad news for labor crested with the passage of the Taft-Hartley Act in 1947. Meanwhile, racial tensions on the job, the ravages of inflation, and rising material expectations all added to the mounting discontent of American workers. A sharp recession in 1949, during which the unemployment rate nearly doubled to 8 percent, fueled the fire. Organized labor had real reason to fear the return of Depression conditions.

Relief came, expectedly, in the form of a new, more intense phase of the Cold War. Truman's national security staff, aided by labor-friendly economist Leon Keyserling, drafted NSC-68 in 1949, calling for major increases in defense spending--a buildup Keyserling insisted would invigorate rather than burden the economy. (8) With diminishing options for a social Keynesian spending program, the mainstream of organized labor embraced military Keynesianism. The shift fit the conservative tenor of the times. "Military spending doesn't really alter the structure of the economy.... But the kind of welfare and public-works spending that Truman plans ... creates new institutions. It redistributes income," opined Business Week in 1949.(9) Business leaders were clearly more open to military Keynesianism than to its social-spending alternative. Planners in the organized labor movement, however, plotted to turn Business Week 's equation on its head--to harness defense spending to address pressing economic and social problems.

Already, Amalgamated Clothing Workers President Sidney Hillman had offered a prototype for such plans in the days leading to Pearl Harbor. As a member of the National Defense Advisory Council (NDAC), in 1940, he developed a program aimed at directing defense mobilization dollars to areas and industries still suffering from the Great Depression. While the NDAC, after some reluctance, issued a statement endorsing Hillman's plan, longstanding hostility between organized labor and the military--which historian Paul Koistinen described as "rife with virulent labor-haters"--combined with the pressure of wartime mobilization to thwart labor's hopes for implementing the plan. (10)

Facing recession and a hostile political scene, labor took a renewed interest in Hillman's plan. An embrace of military Keynesianism appealed to labor on a number of levels. A 
firm Cold War posture appealed to the vehement anticommunism of many trade unionists. Likewise, the defense sector operated partly in the public sphere, and as such was less driven by market forces and more open to political influence. (11) In the face of determined opposition, this semipublic realm, many in labor believed, offered the only realistic venue through which to pursue socially conscious, equitable economic growth.

\section{War and Opportunity}

The unexpected arrival of war in Korea in June 1950 gave labor the opportunity to pursue its agenda for defense spending. Dedicated to a vision of pluralistic governance, trade union leaders resolved to have influence in shaping the defense buildup--a real voice that would not be drowned out by competing interests, as they believed had been the case during World War II. (12) Although at times seeming to resent the power and influence of trade unions, President Truman understood the debt he owed labor for his 1948 surprise victory and sought to build support for his Korean initiative. Initially, he welcomed trade union participation in defense planning and sought to provide labor with the influence it demanded. (13)

The AFL and CIO--putting aside their often bitter differences--formed a joint committee, the United Labor Policy Committee, to coordinate a response to the crisis. Truman ordered each major defense agency to take on a labor advisor. A Committee on Defense Manpower and National Labor-Management Policy, with several labor representatives, convened within the Labor Department to oversee the nation's manpower requirements. (14) Trade unionists on the committee seized it as a forum to advocate policies directing spending to "labor surplus areas. “(15) Jacob Potofsky, Hillman's successor as president of the Amalgamated Clothing Workers, for instance, aggressively pressed for accelerated procurement of textiles and policies that would mandate "respect for labor standards" in the awarding of contracts. (16)

Human impact, insisted Potofsky, alongside concerns for optimal efficiency and lowest cost must be weighed in the awarding of contracts. Potofsky aimed specifically to aid the severely slumping textile industry, and, by mandating labor standards, slow the drain of textile jobs to the non-unionized South. His agenda, however, went well beyond the textile industry. Ultimately, trade unionists sought to commandeer the growing defense establishment--to make it as responsive to the goals of promoting employment and addressing social needs as to fighting the Cold War.

During the first several months of the Korean mobilization, organized labor aggressively pursued its defense-spending agenda. By late 1950, however, it became clear to Truman that the war would last longer than he had hoped and that full mobilization required greater organization and centralized authority. In a sweeping move, the president consolidated control of defense production in one office under General Electric President Charles Wilson. Trade unionists feared that a businessman commanding so central and powerful a position might prove an obstacle to their initiatives. Their fears were immediately realized. Taking office, Wilson established his own manpower policy committee staffed with non-labor advisers. He permitted the labor-management 
committee to continue its work-but it was to operate only in an advisory capacity. Committee members fumed at Wilson's autocratic approach. When they met on 13 February 1951, their anger boiled over. Fearing that his efforts to accelerate textile procurement and address other economic problems were in vain, Potofsky incited members to dissolve their committee in protest. (17)

Wilson's strike at pluralistic governance continued to reverberate. "There is absolutely no desire on the part of Mobilization Director Charles Wilson to give labor a real voice in the formulation of defense policy," complained the joint AFL and CIO United Labor Policy Committee. It soon called for labor representatives in all other defense mobilization agencies to "resign immediately." (18) Although controversy over wage and price stabilization contributed to the walkout, labor's strong desire to shape manpower and procurement decisions was the primary motivation. (19) The walkout was to be a clear statement--unlike the previous war, this time trade unionists were hell-bent on having a real policy-making role. The walkout quickly revealed the president to be a fair weather friend. "There is a conspiracy between labor and management to gouge the country," bristled Truman to his cabinet. (20)

Still, the president felt pressured by labor's political influence and the national emergency. He, in turn, pressured Wilson. After several months of standoff, in late April 1951, the mobilization czar capitulated and granted substantial, substantive labor participation on policy-making bodies. (21)

Wilson's concession provided organized labor with a well-situated forum to put forth its agenda; hence, labor dropped its boycott. But as the Office of Defense Mobilization hashed out the new representation arrangement, all sides recognized that the $\mathrm{CIO}$ and AFL remained too divided to share power effectively. Instead, one labor office was established within the Defense Production Agency, headed by AFL Vice President Joseph Keenan, while a separate office was created in the National Production Authority (NPA) under O. A. Knight of the Oil Workers-CIO. The arrangement caused problems of "over-lapping authority," but it limited rivalries. (22)

From their new forums, labor officials did achieve some real, although admittedly not overwhelming, success in shaping defense policy-in particular, harnessing war mobilization to address the problem of depressed areas and industries. Of the two offices, the CIO's Labor Office in the NPA quickly proved the more aggressive. Knight's staff immediately moved to line up support from congressmen in labor surplus areas, i.e., regions with high unemployment. They conducted well-publicized meetings with delegations of unemployed workers, such as CIO textile workers from hard-hit Lawrence, Massachusetts. The NPA's message was clear: regrettable idleness existed at a time of national emergency and mobilization. Building on its public relations campaign, the labor office commissioned a survey of area unemployment conducted in the fall of 1951. The study--focusing on the plight of Belmont and lower Jefferson counties in Ohio, which were coincidentally the district of influential congressman Wayne Hayes, who desperately sought help for his beleaguered constituency--uncovered distressing unemployment and economic stagnation. (23) 
The release of the survey, essentially the Office of Labor's opening salvo, was not greeted warmly by military officials, who were reluctant to take on the additional burden of broad economic planning. During World War II, military officials resolutely resisted cooperation with organized labor, moving instead to cement what Brian Waddell recently called a "corporate-military alliance." (24) During the Korean War, the alliance seemed to hold. The Army had no authority, military officials claimed, to award contracts on any basis other than lowest cost. The Office of Labor countered by producing an apparently forgotten memorandum written the previous year by Secretary of Defense George Marshall, in which the secretary advised that "availability of manpower in distressed employment areas or in areas of manpower shortages" should be among the factors considered in defense procurement. (25) Finally, the debate went to the Comptroller General who ruled in favor of the Nap's view. (26)

With building political pressure from labor and interested congressmen, Wilson issued Defense Manpower Policy \#4 (DMP\#4) on 7 February 1952. (27) The policy granted special consideration to regions officially designated "labor surplus areas" by the existence of an unemployment rate of 6 percent or more. On paper at least, trade unionists working on mobilization agencies, in spite of resistance from both the military and business interests, had achieved their goal: they had a policy essentially imposing their socially conscious agenda on the military-industrial complex. While initiatives of various sorts to influence defense spending were hardly novel, DMP\#4 broke new ground as a formal, government-issued policy. For that alone it was significant.

Having a policy on the books, however, was only half the battle-implementing it involved a whole new struggle. Armed with the new policy, O. A. Knight's able assistant, veteran CIO staffer Ted Silvey, who handled the day-to-day operations of the Office of Labor, took the initiative. The most pressing issue was how to award contracts under the new system. Silvey advocated a procedure in which contracts or portions of defense contracts would be "set aside" for labor surplus area firms and regions. Procurement officers were to negotiate set-aside contracts directly with firms in distressed areas with every effort made to keep bids within the general price range of the open bidding process. However, the Department of Defense simply chose to ignore Wilson's directive. Assistant Secretary of Defense Anna Rosenberg--dismissively explaining that she did not believe DMP\#4 placed the Defense Department under any obligation to direct contracts to areas where unemployment was not a result of defense conversion--refused to attend meetings dealing with DMP\#4 procedures. (28)

In spite of determined resistance to the policy, the tireless dedication of Silvey and other laborites eventually resulted in the military's acceptance of two methods to direct spending to surplus areas. The first arrangement offered firms in labor surplus areas the opportunity to meet the lowest bid on a certain contract if bids came within 20 percent of the lowest bid. The second method reserved contracts or portions of contracts for labor surplus areas. This procedure did not require a contractor in such an area to meet a lowest bid, although some bidding and negotiations still took place. The mandate that human needs and macroeconomic planning be factored into contract decisions, so that defense contracting operated somewhat outside of the bounds of strict market forces, galled many 
in the military. Laborites, however, felt they had found a force to soften the cold inequalities of the market.

To counterbalance military indifference, both the Defense Production Agency and the NPA aggressively promoted the new system of distressed area preferences. The NPA sponsored clinics in twenty-four cities in an effort to place contracts. Meanwhile, the DPA created a Defense Distressed Areas Task Force aimed particularly at helping slumping Detroit take advantage of defense contracts. (29) The NAP Office of Labor exerted influence in other ways as well. It helped, for instance, ease raw materials restrictions to keep workers on their jobs at Oneida, Ltd., a flatware and silver manufacturer located in a labor surplus area in upstate New York. (30)

Within a year, Silvey and Knight were relatively pleased with their progress. Between late March and December 1952, procurement officers awarded more than $\$ 1.5$ billion in defense contracts to surplus areas, although only roughly $\$ 48$ million involved preferential arrangements. Of sixty localities originally certified as surplus areas, the situations in twenty-one of the sixty already allowed for their removal from the distressed list by March 1953. Beyond this, Silvey held that the Office of Labor's education outreach efforts had paid off simply by advising firms in distressed areas of available contracts, often awarded with winning bids without preferences. With increased public relations and greater cooperation from the Defense Department, Silvey and associates hoped that preferences could draw even more dollars into distressed areas. (31)

In practice, however, numerous procedural problems complicated the process. For instance, procurement officers often accepted multiple bids on the same products at different price levels. When firms in distressed areas were extended the opportunity to meet bids, Silvey in the Office of Labor argued that a labor surplus area bid need meet only the highest bid, whereas military procurement officers insisted on the lowest bid. An ongoing battle on this and a plethora of other issues continued to rage between organized labor and the military.

Beyond administrative tensions, the benefits of the preference programs seemed to bypass certain industrial areas. DMP\#4, for instance, did little to aid the textile industries in distressed New England, where unemployment had soared as firms moved South in search of cheaper labor. Dismay at the faltering New England textile firms originally had inspired Potofsky and others with the plan to aid distressed areas. By early 1952, however, the textile industry was in a deep depression, and New England mills were hardest hit. Worsted and woolen mills in New England operated at roughly 40 percent capacity. (32) Regional tensions, however, impeded efforts to help the collapsing industry. Before preferences could be granted, the rules governing DMP\#4 required a national public hearing to assess the impact of regional preferential treatment on the national health of the particular industry. With the textile industry split between the largely unorganized South and the dying Northern mills, the industry hearing on 20 March 1952 yielded a bitter stalemate. In place of preferences for particular regions, the Office of Defense Mobilization developed a weak compromise formula, favoring plants operating eighty hours or fewer per week. But the eighty-hour arrangement proved nearly 
impossible to administer. Factories working at limited capacity struggled to meet lowest bids, and, with regional tensions flaring, the Defense Department chose simply to disregard the preferential policy when it came to textiles. (33) Nor could trade unionists muster broad popular support for the programs, with attention diverted in 1952 by President Truman's seizure of the steel industry and a subsequent fifty-three-day strike by steelworkers after the Supreme Court ruled the president's actions unconstitutional. (34)

With New England textile towns such as Lawrence nearing extinction, Ted Silvey stewed angrily. "To exclude the textile industry entirely from area preference," Silvey wrote to the acting head of Defense Mobilization, "would not assure giving aid where it is needed most. ... the Communist party has seized on the acute distress in Lawrence for propaganda purposes as evidenced by their attempts to attract people to a communist rally in that city." Not even Silvey's evocation of the "great fear," however, could help New England's textile industry. (35) The Office of Labor continued to press the issue, but the collapse of the textile industry in New England continued largely unabated. (36)

The frustrations of working through an uncooperative military underscored for many trade unionists the limits of preferential programs. Real change required a more fundamental commitment to full-employment policies. But such a commitment remained unlikely, with the country still very much in a conservative mood. In the absence of social Keynesian alternatives, DMP\#4 offered vital, albeit limited, aid to struggling industries, communities, and people.

\section{"I've Always Liked Bird-Dogs Better Than Kennel-Fed Dogs"}

By early 1953, the conflict in Korea was winding down, and Americans had elected Dwight Eisenhower as their president partly on his promise to lift wartime controls on the economy. Republicans also took control of the Senate, essentially dooming social welfare legislation. The new president brought to the executive branch a more conservative fiscal approach and real skepticism about ballooning defense expenditures. Eisenhower was no Keynesian--not even a military Keynesian.

Things took a downward turn for labor's defense agenda almost immediately. With the national emergency over, the National Production Authority's Office of Labor disbanded on 13 April 1953. As a result, labor lost its position on the inside policy-making track--a bureaucratic niche it never regained. Trade unionists could only hope that Eisenhower was sincere during the campaign when he told unemployed textile workers in Lawrence, Massachusetts, that he favored preferential programs. (37) In office, however, Eisenhower appeared to forget his promise. On 19 August 1953, the Office of Defense Mobilization suspended all preferential policies in the granting of defense contracts.

Eisenhower's critics enjoyed dismissing his cabinet as "nine millionaires and a plumber." During his brief tenure in office, the plumber, Secretary of Labor Martin Durkin, tried to develop new policies to favor depressed areas, but the conservative atmosphere in the 
new administration frustrated his labors. By late 1953, however, the economy was losing steam. Reconversion from the war and Eisenhower's insistence on cutting spending, particularly defense spending, weakened the economy. Unemployment edged upward, and the president worried that he, like the previous Republican in office, might be blamed for a depression. In a pattern that repeated itself with every economic downturn, labor used the slowdown as a pretext to call for higher defense spending and a revival of DMP\#4. Just after Christmas, Eisenhower issued a memorandum urging federal agencies to cooperate in a renewed effort by the Office of Defense Mobilization to place defense contracts in labor surplus areas. (38)

Opponents of preferences, however, refused to stand by idly. The threatened return of preferential treatment in granting contracts stirred a minor upheaval among southern senators. Senator William Fulbright (Democrat-Arkansas) worried that the policies "opened the door to all kinds of favoritism." Senator Burnet R. Maybank of South Carolina called the president's initiatives "outrageous." But perhaps the scales were tipped when William Knowland, the leader of the Senate Republicans from California (a state in which one-third of nonagricultural workers depended on defense industries), added his voice to those protesting preferences. (39) Sensing trouble, Eisenhower retreated. On 15 January 1954, the president noted to reporters certain "misapprehensions" about his advocacy of preferences and dismissed the "exaggerated idea that entire contracts would be shoved somewhere just because they had unemployment." (40)

Eisenhower did implement a scaled-down version of preferences, but-as developments during the Korean War suggested--policy initiatives and directives by themselves accomplished little. Success required inside bureaucratic vigilance and affirmative action. With no core of activists in the Eisenhower administration and virtually no support from the executive, failure was almost guaranteed. In the first quarter of 1954, defense contracts awarded through preferences amounted to only a meager $\$ 163,149$. Textile preferences amounted to only $\$ 16,214$--virtually nothing. (41)

Charles Wilson (not to be confused with the Charles Wilson in charge of the Defense Mobilization under Truman), Eisenhower's Secretary of Defense and the former chairman of the board of General Motors, underscored the half-hearted nature of Eisenhower's efforts on behalf of distressed areas. During a tour of the West, Wilson likened workers who called for area preferences to "kennel dogs" who sit on their "fanny and yell" for defense dollars. "I've always liked bird-dogs better than kennelfed dogs myself," the secretary added. Wilson's comments drew both headlines and a sharp rebuke from AFL President George Meany who assailed Eisenhower's "big business administration." (42) Yet it was clear that the Defense Department was no longer even mildly committed to pursuing initiatives such as Defense Policy \#4. (43)

With the door essentially shut on preference programs, organized labor turned to the more generalized tier of its approach to the military-industrial complex. Still committed to promoting pro-growth military Keynesian spending, labor continued its call for overall increases in defense outlays, which it believed fueled economic growth and spurred 
recovery from downturns. (44) A stable, growing economy, lifting workers into a more secure middle-class existence, remained the primary goal of postwar labor; defense spending offered a viable route to that destination.

After several good economic years following the recovery from the 1954 recession, tight fiscal and monetary policies led to a second Eisenhower recession in late 1957 and into 1958. By the spring of 1958, the Labor Department had added twenty-one communities to its list of areas with substantial labor surpluses (unemployment rates of over 6 percent), including Youngstown, Ohio; Bridgeport, Connecticut; and St. Louis, Missouri. Nationally, unemployment quickly soared above 7 percent. With workers losing their jobs and the administration seemingly indifferent, labor vocally demanded action. In March, Eisenhower reluctantly agreed to meet with an eight-man AFL-CIO delegation. The group aggressively pressed the president for public works and defense spending, along with a recommended tax cut and expanded federal unemployment insurance. The president demurred. (45)

The Soviet launching of Sputnik several months later, however, forced the president to rethink his position. With the recession still strangling growth, George Meany moved to conscript Cold War fears for his economic agenda. Unemployment, he warned, "could very well lead to a situation for which the Kremlin has been hoping and expecting--the collapse of the U.S. domestic economy which could give the Soviet Union a victory over us without firing a shot." (46) Noting the concurrent domestic and international crises, in February 1958, the AFL-CIO Executive Council argued that in each problem lay the solution to the other. With America's military superiority clearly "slipping" and the national economy "declining ... idle factories and machines" were "robbing us of billions of dollars of potential production of military and civilian goods," claimed the council. The administration, however, remained mired in "penny pinching and budget-balancing." Assailing Eisenhower's cutbacks in aircraft, ships at sea, and active personnel, the AFLCIO declared that "the time is now--not tomorrow--for a bold program to lift the economy out of its slump and national defense out of its dangerous lag ... Prosperity and strong national defense are both feasible." (47)

Eisenhower--privately bemoaning "Sputnik complexes"--met the federation halfway, approving defense increases of roughly $\$ 1.1$ billion in 1958 and requesting a $\$ 5$ billion increase in the national debt limit, thus easing his restrictive fiscal policies. (48) At the same time, the Federal Reserve Board reacted to pressure by easing the discount rate, another demand of organized labor. (49) Eisenhower's new outlays, combined with new expenditures for a federal highway system and other spending, pulled the country out of the recession, at least temporarily. Before Congress the next year, United Auto Workers President Walter Reuther credited the recovery to increased defense spending. (50) Sputnik and the recession offered an indelible lesson to labor and Keynesians: while unemployment alone failed to bring government to action, economic worries combined with a national security crisis, such as that provided by Sputnik, created a climate ripe for spending initiatives. (51)

Operation Booster 
Laborites greeted the election of John F. Kennedy in 1960 with high hopes of more vigorous spending policies to spur economic growth. Representing Massachusetts in Congress, Kennedy had been both a benefactor and beneficiary of programs such as DMP\#4. During the 1960 election, Kennedy profited from a staggering economy and a general sense that America was losing the Cold War. His campaign vow "to get America moving again" and to expand American military capabilities resonated strongly with trade unionists.

The help was very much needed. Rising unemployment and the second recession in three years as Kennedy took office greatly concerned labor. "The country stands today on the threshold of the gravest economic crisis since the great depression of the thirties," George Meany warned Speaker of the House Sam Rayburn in early 1961.52 Alongside higher defense spending, the AFL-CIO called for a thirty-five-hour week and an aggressive public works program. The twin factors of a sympathetic president and an economic downturn boded well for a revival of programs such as DMP\#4.

President Kennedy moved quickly to address the issue of unemployment. He signed the Douglas Area Redevelopment Act in early 1961 and unshackled defense spending. (53) After several years of virtual nonenforcement, Kennedy also moved to revive DMP\#4. He instructed his Secretary of Defense, Robert S. McNamara, to begin a vigorous program of directing defense contracts to labor surplus areas, dubbed Operation Booster. (54) Kennedy and McNamara pressured subordinates to enforce the revived policies. The Army's Quartermaster General in turn issued a memo to procurement officers explaining that it is the "duty of the Department of Army to respond to this request by exerting every possible effort to alleviate this most pressing economic problem." (55) The deputy assistant secretary of defense for supply and logistics likewise ordered subordinates to take "active steps" to direct contracts to labor surplus areas. (56)

Despite Kennedy's initial urgency, the plan proved difficult to implement. Within a year, supporters felt forsaken. By early 1962, Secretary of Labor Arthur Goldberg complained openly about a missile contract going to an area of California with a skilled worker shortage rather than to a Baltimore corporation in a labor surplus area. (57) The AFLCIO was soon assailing the Kennedy administration's "timid" approach to economic problems. (58) At a senate hearing in 1962, Senator Hubert Humphrey bitterly noted that the "distressed area set-aside is a policy of this Government and I think somebody ought to find out why it is not being implemented." Reflecting growing regional tensions over the issue, the Minnesotan suggested the military perhaps was "too busy wanting to get out to the sunshine, where they can just flit around out there on the beach." (59)

The partial recovery of the economy removed the immediate imperative for Operation Booster. More than sun worship and returning prosperity, however, was behind the desertion of preferential policies under Kennedy. Following President Eisenhower's farewell address warning about the "military industrial complex," and the increasing expression of concern on the part of economists such as Seymour Melman, President Kennedy--through Robert McNamara--launched a crusade to depoliticize, modernize, and reorganize defense procurement. (60) Under Budget Director David Bell, Kennedy 
initiated an extensive study of defense contracting, with the help of a grant from the Ford Foundation. The Bell report, issued in 1962, uncovered significant waste in defense contracting. To organized labor, a certain level of inefficiency was acceptable if the result was jobs. Such was not McNamara's view.

Using the Bell report he helped craft, the secretary of defense set out to impose a new business-like efficiency on the military-industrial complex. He consolidated the farreaching procurement offices of the military into one body, the Defense Supply Agency (DSA), to be guided by the principle of keeping inventories low and "buying only what we need at the lowest price possible." Previously, most military contracting had been placed through a system known as "cost-plus" contracting, allowing contractors to charge for costs incurred plus a guaranteed profit. In certain cases, as McNamara persistently bemoaned, a contractor might actually jeopardize profits if he reduced costs. In place of such contracts, McNamara proposed "fixed-price" or "price-incentive contracts" in which contractors took greater risks and earned rewards for efficiency. (61)

McNamara, like Wilson before him, a former automobile executive, saw little reason to consult a "special interest" like the AFL-CIO in policymaking and saw little to be gained from labor officials operating in his department at cross purposes with his efficiencydriven efforts. The secretary flatly rejected George Meany's nomination of AFL-CIO Vice President Joseph Keenan to be the assistant secretary of defense for manpower issues. (62) Throughout the Kennedy presidency, organized labor complained loudly, as they had during the Eisenhower administration, of a lack of representation on key defense decision-making bodies. (63) Without an official representative in the Defense Department, labor could do virtually nothing to block McNamara initiatives, such as reversing the 1933 "Buy American" Act and opening up bidding for the construction of small naval vessels to foreign competition. (64)

In spite of his early endorsement of Operation Booster, McNamara later publicly disavowed any social role for defense spending. "We don't propose to turn the defense industry into a WPA. We are going to buy what we need and only what we need," he announced. (65) In 1964, McNamara rejected a proposal to revive "set-aside programs" from their dormant state. AFL-CIO economist Nate Goldfinger lamented that "there is apparently a feeling on the part of McNamara that the defense program should not be called upon to cope with problems of the economy." (66)

To those seeking limits on the military-industrial complex, McNamara was a hero, at least momentarily. (67) In 1964, McNamara claimed to have saved the nation $\$ 4.1$ billion dollars. (68) The secretary closed bases, streamlined operations, and reined in contractors. But the AFL-CIO saw only job losses at a time when unemployment remained well above full-employment levels due to automation, increasing foreign competition, and slow economic growth. George Meany worried about the 8,500 civilian jobs eliminated in 1963 because of base closings. (69) In a speech at a DOD industry briefing, AFL-CIO Secretary-Treasurer William Schnitzler responded to McNamara by insisting that "[w]e in the labor movement don't want a new WPA whose first two initials stand, not for 'Works Progress' but for 'Weapons Production."' Schnitzler insisted that 
labor was concerned about waste, but added: "we are against the kind of waste represented by unemployment and community bankruptcy. We do not believe that eliminating waste on one front ought to create waste on another." (70)

Although military spending remained an enormous component of the national economy during and after the McNamara era, the nature of the military-industrial complex changed significantly. Under more restrictive contract provisions, defense dollars no longer guaranteed profits. Between 1965 and 1969, the profits of defense contractors Lockheed Aircraft, General Dynamics, and General Electric all fell--despite the Vietnam conflict. The effects of increasing inflation after 1965 rendered fixed-price contracts an evergrowing risk. (71) By the mid-1960s, contracts granted to labor-surplus areas no longer ensured the temporary economic relief on which more permanent recovery might be built. (72)

Thus on the eve of the Vietnam War, organized labor's hopes of reviving its defense spending agenda essentially came to naught. The conflict in Southeast Asia introduced new complex dynamics into the equation. Philip Foner and others have linked the AFLCIO's "unstinting support" for the war to its desire to create jobs for its membership. (73) While the AFL-CIO's anticommunism was grounded in an idealistic hatred for communism separate from pecuniary issues, the logic of military Keynesianism certainly undergirded the labor federation's calls for a hard line on Cold War issues. Organized labor deeply believed that the American economy could thrive producing both guns and butter--preferably with guns produced in such a way as to promote plentiful and equal distribution of butter. The McNamara-controlled defense establishment, however, hardly allowed for this eventuality.

Critics of American organized labor almost unanimously lament labor's support for the military-industrial complex as the product of shortsightedness and an unfortunate corporate compact, producing few gains for workers while imperiling the world. Indeed, the image of trade unions vigorously supporting defense spending did much to widen the rift between the labor movement and the New Left during the 1960s. Realistically, however, had trade union leaders taken a public posture of opposition or even skepticism toward the Cold War and the evolving military-industrial complex, they risked political alienation and a potential economic backlash against their membership. Still, a greater appreciation of the dangers of a rapidly expanding peacetime military might have served labor better in the eyes of its critics and some of its membership.

A full evaluation of labor's defense policy, however, must take into account its creative efforts to mold military outlays into economic tools. In the military-industrial complex, labor found a venue somewhat removed from the cold forces of the market; it hoped, and managed to some extent, to harness defense spending for its social and economic agenda. Certainly organized labor's success was limited--although not to workers who enjoyed jobs as a result of DMP\#4 and increased military spending. At the time, few alternatives existed. Even during labor's supposed heyday of the 1940s and 1950s, substantial economic, political, social, and cultural forces circumscribed the capacity of trade unions to shape their own destinies. And even when working within the system as a supporter of 
the military-industrial complex, labor met substantial resistance from an antagonistic military, conservative politicians, and civilian businessmen, hostile to organized labor and determined to apply the logic of the market to the military-industrial complex. Facing these forces, labor struggled to make the best of what it had.

\section{Footnotes}

1. For my purposes, President Dwight Eisenhower's simple definition of the militaryindustrial complex is appropriate: the "conjunction of an immense military establishment and a large arms industry." Throughout the paper, I use the term "labor" to refer to the mainstream labor movement. While organized labor cannot be treated as a monolith, during the immediate postwar years a concrete consensus on central issues did exist. Where disagreements occurred, I point them out.

2. For one of the most sophisticated of these studies, see Nelson Lichtenstein, "From Corporatism to Collective Bargaining: Organized Labor and the Eclipse of Social Democracy in the Post-War Era," in The Rise and Fall of the New Deal Order, eds. Steven Fraser and Gary Gerstle (Princeton, NJ: Princeton University Press, 1989), 122152. Also see works by Christopher Tomlins, Patrick Renshaw, and Michael Davis.

3. Ellen Schrecker, "The Legacy of Charles Owen Rice," Labor History 40 (February 1977): 66.

4. Michael Hogan, Cross of Iron: Harry S. Truman and the Origins of the National Security State, 1945-1954 (New York: Cambridge University Press, 1998). Hogan depicts a postwar struggle to define the nature of the emerging national security state. My study portrays U.S. organized labor's contribution to that process and outcome. While mainstream labor sided with those who supported a strong national security state, it sought to shape defense spending toward its own full-employment ideals.

5. Robert Zieger, CIO (Chapel Hill, NC: University of North Carolina Press, 1995), 313; Margaret Wier and Theda Skocpol, "Social Structures and the Possibilities for Keynesian Responses to the Great Depression in Sweden, Britain, and the United States," in Bringing the State Back In, eds. Evans et al. (New York: Cambridge University Press, 1985), 108, 137-145.

6. The most consistent spokesperson for these "labor idealists" has been Nelson Lichtenstein.

7. On the business campaign against labor, see Elizabeth Fones-Wolf, Selling Free Enterprise: The Business Assault on Labor and Liberalism, 1945-1960 (Urbana, IL: University of Illinois Press, 1994).

8. John Lewis Gaddis, Strategies of Containment: A Critical Appraisal of Postwar American National Security Policy, 2nd ed. (New York: Oxford University Press, 1992), 197; Ernest May, ed., American Cold War Strategy: Interpreting NSC-68 (Boston: St. 
Martin's Press, 1993), 106, 154; Robert M. Collins, More, The Politics of Economic Growth in Postwar America (New York: Oxford Press, 2000).

9. As quoted in Brian Waddell, The War Against the New Deal (DeKalb, IL: Northern Illinois University Press, 2001), 158.

10. Stephen Fraser, Labor Will Rule: Sidney Hillman and the Rise of American Labor (New York: Cornell University Press, 1991), 452, 256-458; Paul Koistinen, The Hammer and the Sword: Labor, the Military, and Industrial Moblization, 1920-1945 (New York: Ayer Co., 1979), 1, 128-239, 336.

11. On the non-market nature of the military economy, see Merton J. Peck and Frederic M. Scherer, The Weapons Acquisitions Process: An Economic Analysis (Boston: Harvard Business School Division of Research, 1962), 55-66; and David Noble, Forces of Production: A Social History of Industrial Automation (New York: Oxford University Press, 1982), 332-335.

12. Zieger, 294. As Robert Zieger argues, "CIO leaders hoped to translate their support for war into a partnership in the management of the economy upon which the military effort rested."

13. On the overall Korean War mobilization, see Paul G. Pierpaoli, Truman and Korea: The Political Culture of the Early Cold War (Columbia, MO: University of Missouri Press, 1999); and Hogan, 265-365.

14. Minutes of Defense Manpower Committee Meeting, 14 December 1950.

Interdepartmental Committee on Defense Manpower and National Management-Labor Policy, 1950-1, box 1, General Records of the Labor Department, RG 174, National Archives, College Park, MD (hereafter NA).

15. "Confidential Minutes of Meeting 2," 27 December 1950. Interdepartmental Committee on Defense Manpower and National Management-Labor Policy, 1950-1, box 1, General Records of the Labor Department, RG 174, NA.

16. "Memoranda to Management-Labor Policy Committee," 25 January 1951. Interdepartmental Committee on Defense Manpower and National Management-Labor Policy, 1950-1, box 1, General Records of the Labor Department, RG 174, NA.

17. Minutes of Committee on Defense Manpower and National Management-Labor Policy, 13 February 1951. Interdepartmental Committee on Defense Manpower and National Management-Labor Policy, 1950-1951, General Records of the Labor Department, RG 174, NA.

18. ULPPC Statement, 28 February 1951, National Production Authority, Labor Participation in Production for Defense: A History of the Office of Labor (Washington, DC: 1953), appendix E. This discussion of Defense Manpower Policy \#3 is based largely 
on two histories of the activities of the National Production Authority (NPA) produced by the agency's Office of Labor in 1953: Labor Participation in Production for Defense: A History of the Office of Labor, and Defense Manpower \#4 and the History of the Surplus Manpower Committee. Both reports, deposited at the AFL-CIO Library, contain a narrative history of NPA Office of Labor activities and appendices of documents relating to NPA work. Subsequent references to the narrative portion of the reports will contain the title and a page number. References to the

19. Jack Stieber, "Labor's Walkout from the Korean War Wage Stabilization Board," Labor History (Spring 1980): 239-253.

20. Alonzo Hamby, Man of the People: A Life of Harry S. Truman (New York: Oxford University Press, 1995), 578.

21. Ibid.; Robert Donovon, Tumultuous Years (New York: W.W. Norton \& Co., 1982), 326-327.

22. National Production Authority, Labor Participation in Production for Defense: A History of the Office

23. O. A. Knight and G. Wayne Morgan, "Unemployment and Distress in Belmont County and Lower Jefferson County," 8 November 1951, DMP \#4 and the Surplus Manpower Committee.

24. Waddell, War Against the New Deal, 3.

25. General Marshall to the Secretaries of Army, Navy and Air Force, 18 December 1950. Defense Manpower Policy \#4 and the Surplus Manpower Committee [Appendix 2].

26. Lindsay C. Warren to Charles Wilson, 14 January 1952, Defense Manpower Policy \#4 and the Surplus Manpower Committee.

27. Zieger, 299. Zieger argues that despite the success of the walkout, organized labor was "still locked-out of major decision-making forums." But the adoption of DMP\#4, which Jacob Potofsky had identified as a key ideal in the mobilization effort, did represent a major achievement for labor.

28. Defense Manpower Policy \#4 and the Surplus Manpower Committee, 16.

29. Memorandum from O. A. Knight, 20 February 1952, Labor Participation in Production for Defense, A History of the Office of Labor [Appendix G].

30. Labor Participation in Production for Defense: A History of the Office of Labor, 14; New York Times, 29 September 1951. 
31. Defense Manpower Policy \#4 and the Surplus Manpower Committee, 42-43.

32. John Herling's Labor Letter, 9 February 1952.

33. "Important Actions Affecting Textile Procurement Under DMP\#4 as of March 10, 1953," Labor Participation in Defense Production [Appendix U4].

34. On the steel strike, see Hamby, Man of the People, 593-597. Complaining that the administration had become a puppet of organized labor, Charles Wilson resigned in reaction to Truman's handling of the steel crisis.

35. Defense Manpower Policy \#4 and the Surplus Manpower Committee, 30-31.

36. Ibid., 38.

37. Washington Post, 22 October 1952.

38. Public Papers of the Presidents of the United States: Dwight D. Eisenhower, 1953 (Washington, DC: 1959), 861.

39. New York Times, 27 August 1953; 30 December 1953. On southern opposition to DMP\#4 and the transforming impact of defense spending on the South see Bruce Shulman, From Cotton Belt to Sunbelt (New York: Oxford University Press, 1991), 139173. Christopher Preble, "The Political Economy of Cold War Spending." Unpublished paper, available from author upon request. Senator Burnet R. Maybank of South Carolina was a particularly vehement opponent of preferential policies. In 1953, he moved to insert language in defense appropriation bills prohibiting preferential awarding of contracts. The inserted prohibition became known as the Maybank amendment and continued to find its way into legislation after Maybank's death in 1954.

40. Public Papers of the Presidents of the United States: Dwight D. Eisenhower, 1954

(Washington, DC: 1959), 51.

41. The New York Times, 26 May 1954.

42. AFL News-Reporter, 15 October 1954.

43. Alton Lee, "Federal Assistance to Depressed Areas in the Postwar Recessions," The Western Economic

44. Despite the Eisenhower administration's resistance to broad policies directing defense spending to distressed areas, the AFL-CIO continued to lobby the Defense Department, often successfully, on behalf of worker interests in the defense industry. See George Riley to Andrew Biemiller, 12 June 1958, 13/40, Department of Legislation, George Meany Memorial Archives, Silver Spring, MD (henceforth GMMA). For instance, in mid-1958, the AFL-CIO arranged a meeting between procurement officers at the 
Pentagon and union representatives from the Blaw-Knox Iron Casting Company from East Chicago, Indiana. The union members successfully used the meeting to plead for subcontracting work for their plant. For similar initiatives, see Fred J. Cook, The Warfare State (New York: Collier Books, 1964), 178-179.

45. AFL-CIO News, 15 March 1958; "Statement of the AFL-CIO General Board," 28 April 1958, 1/5, Stanley Ruttenberg Papers, GMMA.

46. George Meany speech on NBC radio, 8 January 1958, 60/1, Meany Papers, GMMA.

47. AFL-CIO Press Release, "Statement of the Executive Council: Defense and Economic Growth," 9 February 1958.

48. Herbert Stein, The Fiscal Revolution in America (Chicago: University of Chicago Press, 1969), 320.

49. John Sloan, Eisenhower and the Management of Prosperity (Lawrence, KS: University of Kansas Press, 1991), 122.

50. "Balanced Economic Growth and Full Employment." Draft of Walter Reuther statement before Joint Economic Committee, 30 October 1959, 2/12, Ruttenberg Papers, GMMA.

51. Stein, Fiscal Revolution, 320. For a contemporary view of the economic implications of Sputnik, see James Tobin, "The Eisenhower Economy and National Security: Defense, Dollars, and Doctrines," The Yale Review (March 1958). Keynesian economist Tobin wrote that "Sputnik will be well worth the blow it has dealt our national pride if it frees national policy from the shackles of fiscal orthodoxy."

52. George Meany to Sam Rayburn, 9 January 1961, Office of the President, Copy Books, Micro 7, GMMA. Also see "Report of the AFL-CIO Economic Policy Committee Submitted to the Executive Council," 23 February 1961, in Gary Fink, ed., AFL-CIO Executive Council Statements and Reports, 1956-75 (Westport, CT: Greenwood Press, 1977), 759.

53. See Sar A. Levitan, Federal Aid to Depressed Areas, An Evaluation of the Area Redevelopment Administration (Baltimore, MD: Johns Hopkins Press, 1964), for a history of the Area Redevelopment Act.

54. Kennedy to Secretary of Defense, Secretary of Labor, Administrator General Services Administration, 2 February 1961, Procurement Policy Branch, General Correspondence, 1961, Office of the Quartermaster General, RG 92, National Archives. In issuing his directive, Kennedy pointed to previous problems with such policies: "Although for a number of years there has been a government policy to provide assistance to those areas of the country suffering from chronic heavy labor surpluses, very little actually has been done in the way of channeling government procurement contracts to those areas. Perhaps 
the major reason for this is the ineffective machinery that has been set up to accomplish this objective."

55. Memorandum from Major General and Quarter Master General A.T. McNamara, 5261, Procurement Policy Branch, General Correspondence, 1961, box 3, Office of Quartermaster General, RG 92, NA.

56. R.V. Lee, Major General, USA, "Subject: Procurement in Labor Surplus Areas," 11961, Procurement Policy Branch, General Correspondence, 1961, box 3, Office of Quartermaster General, RG 92, NA.

57. New York Times, 5 January 1962.

58. "Statement of the AFL-CIO on the Economy," 23 February 1962, in Fink, AFL-CIO Executive Council Statements and Reports, 910.

59. Impact of Defense Spending on Labor Surplus Areas--1962, 10-11.

60. For a sense of the impact of Eisenhower's farewell address, see David S. Patterson, "The Legacy of President Eisenhower's Arms Control Policies," in Gregg Walker et al., eds., The Military Industrial Complex (New York: Peter Lang, 1992), 217-236. For some early criticisms of the military state, see Seymour Melman, ed., Inspection for Disarmament (New York: Columbia University Press, 1958); and C. Wright Mills, The Power Elite (New York: Oxford University Press, 1956). In spite of its support for defense spending, the AFL-CIO, like Eisenhower, recognized its limitations and problems. See AFL-CIO News, 10 August 1963, where AFL-CIO News columnist Edward P. Morgan praised Seymour Melman's view that the defense budget could be cut by $\$ 22$ billion without harming the economy.

61. "News Conference of the Honorable Robert S. McNamara," 11 July 1963, 13/41, AFL-CIO Department of Legislation, GMMA. H. L. Nieburg, In the Name of Science (Chicago: Quadrangle Press, 1966), 343.

62. Francis X. Gannon, Joseph D. Keenan, Labor's Ambassador in War and Peace (New York: University Press of America, 1984), 138. During the Korean War, Keenan headed the Labor Office of the Defense Production Administration.

63. For examples of labor complaints concerning lack of representation, see "Summary of the Labor Advisory Committee to the Office of Emergency Planning," 20 September 1961, RG 1, Micro 7, US Government Departments, 1960-1961, GMMA. Also see the comments of machinist president P. L. Siemiller to "The Advanced Planning Briefing for the Department of Defense," AFL-CIO News, 16 April 1966.

64. Nieburg, In the Name of Science, 362.

65. Ibid, 356. 
66. Nathaniel Goldfinger memorandum for Marvin, "Resolution on Cutbacks and Shifts in Govt. Contracting," 14 July 1964, 13/41, Department of Legislation, GMMA. U.S.

Congress, Senate, Subcommittee of the Select Committee on Small Business, "Impact of Defense Spending on Labor Surplus Areas--1964" 2nd Session, 88th Congress, 1964, 4041. McNamara also effectively "vetoed" a "labor surplus test procedure" proposed by the DOD Economic Utilization Director.

67. Jules Duscha, "Arms and the Big Money Men: Congressmen, Contractors, and the 'Defense' Pork Barrel," Harpers Magazine, March 1964, 39-47. Nieburg, In the Name of Science, and William Kaufman, The McNamara Strategy (New York: Harper \& Row, 1964), also praise McNamara's efficiency campaign.

68. Nieburg, In the Name of Science, 356.

69. Meany to Fred Rhodes, 17 December 1963. Office of the President, Micro 81, GMMA.

70. William Schnitzler to "Advanced Planning Briefing for Industry conducted jointly by the DOD and National Security Industrial Association," 29 April 1965, 8/8, Schnitzler Papers, GMMA. Statement of the AFL-CIO Executive Council on Awarding of Defense Department Contracts, 6 May 1966. McNamara's grant of \$24 million in procurement contracts to the antilabor textile firm J.P. Stevens \& Co. further infuriated the AFL-CIO.

71. George Berkley, "The Myth of War Profiteering," New Republic, 20 December 1969, $15-18$.

72. By the mid-1960s, many liberal public policy-makers were completing a shift from an orientation toward class/economic issues to focus increasingly on race. This development, begun in the 1940s, no doubt also contributed to the decline of DMP\#4. Paul R. Ignatius to Willard Wirtz, 28 June 1967, box 434, RG 174, General Records of the Department of Labor, Secretary of Labor, Willard Wirtz, National Archives. Assistant Secretary of Labor Paul Ignatius noted in 1967 that there was increasing interest in the "possibility of using federal procurement contracts to expand job opportunities for the disadvantaged." He noted that some changes would have to be made in DMP\#4 to allow for the addressing of such concerns. "News from the Department of Labor," 6 December 1968. In the final months of the Johnson administration, the Department of Labor joined other agencies in sponsoring "Project Value," a program in which 5,600 "hard-core jobless youths and adults" were given training and jobs in Defense Department facilities in forty-one metropolitan areas. The program focused primarily on race. For instance, organizers of the Salt Lake City-Ogden Project Value program trained and employed only Native American youth.

73. Philip S. Foner, American Labor and the Indochinese War (New York: International Publishers, 1971), 20-22. Foner claims, "Guns brought butter to many hitherto unemployed or underemployed and lulled them into support of, or at least indifference to the war." 
